\title{
Physiological, Morphological and Antioxidant Responses of Pediococcus pentosaceus R1 and Lactobacillus fermentum R6 Isolated from Harbin Dry Sausages to Oxidative Stress
}

\author{
Huan Zhang, Jianhang Xu, Qian Chen, Hui Wang and Baohua Kong * (D) \\ College of Food Science, Northeast Agricultural University, Harbin 150030, China; \\ zhanghuan123@neau.edu.cn (H.Z.); xujianhang@neau.edu.cn (J.X.); chenqian@neau.edu.cn (Q.C.); \\ huiwang@neau.edu.cn (H.W.) \\ * Correspondence: kongbh@neau.edu.cn; Tel.: +86-4515-519-1794; Fax: +86-4515-519-0577
}

Citation: Zhang, H.; Xu, J.; Chen, Q.; Wang, H.; Kong, B. Physiological, Morphological and Antioxidant Responses of Pediococcus pentosaceus $\mathrm{R} 1$ and Lactobacillus fermentum R6 Isolated from Harbin Dry Sausages to Oxidative Stress. Foods 2021, 10, 1203. https://doi.org/10.3390/foods10061203

Academic Editors:

Konstantinos Papadimitriou,

Laura Treu, Stefano Campanaro and Marina Papadelli

Received: 27 April 2021

Accepted: 24 May 2021

Published: 26 May 2021

Publisher's Note: MDPI stays neutra with regard to jurisdictional claims in published maps and institutional affiliations.

Copyright: (c) 2021 by the authors. Licensee MDPI, Basel, Switzerland. This article is an open access article distributed under the terms and conditions of the Creative Commons Attribution (CC BY) license (https:// creativecommons.org/licenses/by/ $4.0 /)$.
Abstract: As functional starter cultures and potential probiotics, the ability of lactic acid bacteria to resist oxidative stress is essential to maintain viability and functional properties. This study investigates the effects of $\mathrm{H}_{2} \mathrm{O}_{2}$ at different concentrations $(0,1,2$, and $3 \mathrm{mM})$ on the physiological, morphological, and antioxidant properties of Pediococcus pentosaceus R1 and Lactobacillus fermentum R6 isolated from Harbin dry sausages. The increase in $\mathrm{H}_{2} \mathrm{O}_{2}$ concentration induced a significant increase in reactive oxygen species and a decrease in intracellular ATP levels $(p<0.05)$. Based on scanning electron microscopy, transmission electron microscopy, and electric conductivity analysis, $\mathrm{H}_{2} \mathrm{O}_{2}$ stress caused cell deformation, the destruction of cell membrane integrity, partial loss of the cytoplasm, and an increase in the cell conductivity of both strains. $\mathrm{H}_{2} \mathrm{O}_{2}$ stress with $1 \mathrm{mM}$ or $2 \mathrm{mM}$ concentrations could effectively improve the scavenging rates of free radicals, the activities of superoxide dismutase and glutathione peroxide, and the total antioxidant capacity of both strains $(p<0.05)$. In conclusion, an appropriate oxidative stress contributed to the activation of the antioxidant defense system of both strains, conferred strains a better effect in inhibiting the oxidation of fermented foods, and improved the health of the host.

Keywords: probiotics; Pediococcus pentosaceus; Lactobacillus fermentum; oxidative stress; cell morphology; antioxidant activity

\section{Introduction}

Lactic acid bacteria (LAB) are innocuous and beneficial microorganisms extensively used in a variety of fermented foods [1,2], and they are widely used in many functional fermented foods as bio-ingredients [3]. LAB play a crucial role in many fermentation processes, as they control the growth of harmful bacteria and improve the sensory quality and texture of foods [4,5]. In addition, some specific strains of LAB have been demonstrated to have antioxidant potential and can capture and neutralize reactive oxygen species (ROS) to delay or prevent oxidation of fermented foods [6,7]. More importantly, many studies have illustrated that some probiotic LAB strains, especially Lactobacillus, can eliminate excessive ROS to prevent or alleviate several diseases related to oxidative stress [8,9]. Therefore, LAB with antioxidant potential can be used as functional starters for the fermentation of foods and be involved in probiotic fields to bring health benefits to hosts.

During production, storage, or application, LAB as a starter culture easily suffer from various environmental stress factors, including osmotic, salt, acid, oxygen, limited fermentation substrate, and low or high temperature.As probiotics, LAB are vulnerable to various stress factors in hosts, such as ROS, bile salts, gastric juice, and intestinal fluid. All these stress factors may affect the activity and physiological function of LAB [10-13]. Oxidative stress is one of the most common stress factors in bacteria, which usually means the excessive accumulation of ROS [14-16]. Due to the lack of a complete electron transport 
chain and catalases [16,17], LAB are extremely susceptible to the accumulated or acute instant ROS, which can cause the oxidation of cell components, perturb cell activity, and affect the physiological performance and antioxidant activity of LAB [18]. Therefore, the regulation of oxidative stress in $\mathrm{LAB}$ cells is vital for maintaining bacterial viability during production, storage, or application. However, the relationship between oxidative stress tolerance and antioxidant capacity in LAB is still not fully understood.

To cope with oxidative stress, LAB have developed a series of adaptive mechanisms, including the production of reducing enzymes, ROS-detoxifying enzymes, small antioxidant molecules, and protein and DNA repair enzymes [17]. The antioxidant properties of LAB are well documented, and various strains show antioxidant capacity. Research has shown that antioxidant enzymes in LAB play crucial roles in developing resistance to different stress factors [19]. Zhao et al. [20] found that hydrogen peroxide $\left(\mathrm{H}_{2} \mathrm{O}_{2}\right)$-induced oxidative stress in white-rot fungus, Coriolus versicolor, stimulated the activity of intracellular antioxidant enzymes. In the fungus Aspergillus niger (B1-D), oxygen enrichment caused reduced ATP yield and elevated endogenous superoxide [21]. However, there are few reports on the effects of oxidative stress on the physiology and antioxidant capacity of LAB and their antioxidant defense systems.

In our previous study, P. pentosaceus R1 and L. fermentum R6 isolated from Harbin dry sausages showed significant antioxidant potential [4], and they also showed great potential as probiotics [22]. However, little is currently known about the physiological, morphologi$\mathrm{cal}$, and antioxidant properties of LAB under oxidative stress. Thus, the purpose of this trial was to examine the influence of oxidative stress induced by increasing $\mathrm{H}_{2} \mathrm{O}_{2}$ concentrations on the physiological performance of P. pentosaceus R1 and L. fermentum R6 by measuring biomass, ROS, intracellular ATP levels. Furthermore, the morphological characteristics of both strains were revealed by scanning electron microscopy (SEM), transmission electron microscopy (TEM), and electric conductivity. The antioxidant activities of both strains, after treatment with different $\mathrm{H}_{2} \mathrm{O}_{2}$ concentrations, were assessed by analyzing the free radical scavenging rates, reducing power, the activities of superoxide dismutase (SOD) and glutathione peroxidase (GHS-Px), and total antioxidant capacity (T-AOC).

\section{Materials and Methods}

\subsection{Bacterial Strains, Growth Conditions and Colony Counts}

The P. pentosaceus R1 and L. fermentum R6 strains were suspended in MRS broth with $25 \%$ glycerol and preserved at $-80{ }^{\circ} \mathrm{C}$. The activated bacteria were prepared and then inoculated into MRS broth for $12 \mathrm{~h}$ (early stationary phase) for the subsequent experiments. The bacteria were collected by centrifugation at $6000 \times \mathrm{g}$ for $10 \mathrm{~min}$ at $4{ }^{\circ} \mathrm{C}$ and washed three times with sterile phosphate-buffered saline (PBS, $0.1 \mathrm{M}, \mathrm{pH} 7.4$ ), resuspended in fresh sterile MRS broth containing different $\mathrm{H}_{2} \mathrm{O}_{2}$ concentrations $(0,1,2$, and $3 \mathrm{mM})$ at a bacterial concentration of $10^{8} \mathrm{CFU} / \mathrm{mL}$, and incubated at $37^{\circ} \mathrm{C}$ for $1 \mathrm{~h}$. The cells were collected and washed three times with sterile PBS (0.1 M, pH 7.4), and then the bacterial cells were resuspended in PBS. The effect of $\mathrm{H}_{2} \mathrm{O}_{2}$ treatment on the number of LAB viable cells was assessed with the plate count method.

\subsection{Intracellular ROS Levels}

The formation of intracellular ROS in the two strains was quantified using the peroxidesensitive fluorescent probe $2^{\prime}, 7^{\prime}$-dichlorodihydrofluoresceindiacetate $\left(\mathrm{H}_{2}\right.$ DCFDA, Beyotime Biological Technology Co., Ltd., Shanghai, China) fluorescent detection kit. After treatment with different $\mathrm{H}_{2} \mathrm{O}_{2}$ concentrations, $1.0 \mathrm{~mL}$ of cell suspension was washed three times with $0.1 \mathrm{M}$ PBS (pH 7.4), treated with $10 \mu \mathrm{M} \mathrm{H}_{2}$ DCFDA, and incubated in the dark for $30 \mathrm{~min}$ at $37^{\circ} \mathrm{C}$. Finally, the intracellular fluorescence intensity was assessed at $488 / 525 \mathrm{~nm}$ (excitation/emission) using a fluorescence reader (SpectraMax M2e, Molecular Devices Co., Sunnyvale, CA, USA). 


\subsection{Intracellular ATP Concentration}

The intracellular ATP levels in strains were assessed with ATP assay kit (Beyotime Biological Technology Co.). In brief, after three washes with 0.1 M PBS (pH 7.4) solution, the bacteria were lysed with radioimmunoprecipitation assay (RIPA) lysis solution and centrifuged at $12,000 \times \mathrm{g}$ for $10 \mathrm{~min}$ at $4{ }^{\circ} \mathrm{C}$. The supernatant was collected for the ATP assay. ATP working reagents $(100 \mu \mathrm{L})$ were added to a micro-well and left to stand for $5 \mathrm{~min}$. Following this, $100 \mu \mathrm{L}$ of the supernatant was added to the ATP working reagents. Finally, the luminescence intensity of the mixture was recorded with a luminescent plate reader (Thermo Fisher Scientific Inc., Waltham, MA, USA), and the final ATP concentration was expressed as $\mathrm{nmol} / \mathrm{mg}$ protein.

\subsection{Electron Microscopy Analysis}

The effects of oxidative stress on the surface and inner morphology of the bacteria were assessed by SEM and TEM using the method as reported by Sanhueza et al. [23] and Ngamdee et al. [24]. All bacteria cells were immersed in 2.5\% glutaraldehyde overnight at $4{ }^{\circ} \mathrm{C}$. Then, the cells were treated with $1 \%$ osmium tetroxide for $2 \mathrm{~h}$ and quickly washed three times with PBS (0.1 M, pH 6.8). Next, step-gradient dehydration was performed with $30 \%, 50 \%, 70 \%$, and $90 \%$ ethanol concentrations at 15 min intervals; then, the cells were rinsed twice in $100 \%$ ethanol for $10 \mathrm{~min}$. For SEM, the sample dehydration procedure was performed gradually with increasing concentrations of ethyl alcohol $(50 \%, 70 \%, 90 \%$, and $100 \%$ ). The ethanol was subsequently replaced with hexamethyldisilazane, and the samples were freeze-dried and coated with gold-palladium. Photomicrographs were taken using a Scios Dual Beam SEM (Thermo Fisher, Hillsboro, OR, USA). For TEM, after the samples were dehydrated, they were washed twice in propylene oxide, infiltrated in a 1:1 mixture of epoxy resin and propylene oxide at $37^{\circ} \mathrm{C}$ for $1 \mathrm{~h}$, and subsequently infiltrated in a 2:1 mixture of epoxy resin and propylene oxide at $37^{\circ} \mathrm{C}$ overnight before being embedded in pure epoxy resin and polymerized at $60^{\circ} \mathrm{C}$ overnight. Ultrathin sections were cut, stained, mounted, and observed under a H-800 TEM (Hitachi, Ltd., Tokyo, Japan) at 200 kV.

\subsection{Electric Conductivity}

The conductivity of P. pentosaceus R1 and L. fermentum R6 suspensions treated with different $\mathrm{H}_{2} \mathrm{O}_{2}$ concentrations was measured every $10 \mathrm{~min}$ for $60 \mathrm{~min}$ using a conductivity meter (Mettler Toledo FE20/EL20, Shanghai, China) [25].

\subsection{Assessment of Antioxidant Activity}

\subsubsection{Intact Cell Suspension and Intracellular Cell-Free Extract Preparation}

Bacterial cells treated with different concentrations of $\mathrm{H}_{2} \mathrm{O}_{2}$ were washed three times with PBS, and the cell concentrations were diluted to $10^{8} \mathrm{CFU} / \mathrm{mL}$ with PBS. Intact cell suspension was disrupted by ultrasonic cell crusher on ice (JY96-II, Xinzhi Biotechnology Co., Ltd., Ningbo, China) and centrifuged at $8000 \times \mathrm{g}$ for $10 \mathrm{~min}$ at $4{ }^{\circ} \mathrm{C}$ to remove the cell debris, and the supernatant solution was employed as intracellular cell-free extract. The antioxidant activities of the intact cell and intracellular cell-free extract were determined as follows.

\subsubsection{2',2'-Diphenyl-1-Picrylhydrazyl Radical Scavenging Assay}

The $2^{\prime}, 2^{\prime}$-diphenyl-1-picrylhydrazyl (DPPH) radical scavenging rates of the strains were analyzed by following the method of Chen et al. [4]. A $1.0 \mathrm{~mL}$ sample was incubated with $2.0 \mathrm{~mL}$ DPPH ethanol solution for $30 \mathrm{~min}$ in the dark. After centrifugation, the absorbances of the supernatant at $517 \mathrm{~nm}$ were recorded. The following formula was used to calculate the DPPH scavenging rates:

$$
\text { Scavenging rates }(\%)=\left[1-\left(A_{\mathrm{s}}-A_{\mathrm{b}}\right) / A_{\mathrm{c}}\right] \times 100 \%
$$

where $A_{\mathrm{s}}$ denotes the absorbance of the solution containing samples and DPPH, $A_{\mathrm{b}}$ 
denotes the absorbance of the blank (samples and ethanol), and $A_{\mathrm{c}}$ denotes the absorbance of solution without the samples.

\subsubsection{Hydroxyl Radical Scavenging Assay}

The hydroxyl radical $(\bullet \mathrm{OH})$ scavenging rates of the strains were determined, and all steps were performed following the method described by Wang et al. [26]. In brief, an aliquot $(0.1 \mathrm{~mL})$ of sample PBS $(0.2 \mathrm{M}, \mathrm{pH} 7.4), 1.0 \mathrm{~mL}$ of O-phenanthroline $(0.1 \%, w / v)$, $1.0 \mathrm{~mL}$ of $2.5 \mathrm{mM} \mathrm{FeSO}_{4}$, and $0.5 \mathrm{~mL}$ of samples were mixed to obtain a homogeneous mixture; an aliquot $(1.0 \mathrm{~mL})$ of $20 \mathrm{mM} \mathrm{H}_{2} \mathrm{O}_{2}$ was reacted with the mixture to trigger the reaction at $37^{\circ} \mathrm{C}$. After $1.5 \mathrm{~h}$, the mixture was centrifuged $(10,000 \times \mathrm{g}, 10 \mathrm{~min})$, and the absorbance $\left(A_{\mathrm{s}}\right)$ of the supernatant was read at $536 \mathrm{~nm}$. The following formula was adopted to calculate the scavenging rates (\%):

$$
\text { Scavenging rates }(\%)=\left[\left(A_{\mathrm{s}}-A_{0}\right) /\left(\mathrm{A}-A_{0}\right)\right] \times 100 \%
$$

where $A_{\mathrm{s}}$ represents the absorbance of the reaction mixture, $A_{0}$ represents the absorbance of the reaction mixture without sample, and A represents the absorbance of the reaction mixture in the absence of $\mathrm{H}_{2} \mathrm{O}_{2}$.

\subsubsection{Superoxide Radical Scavenging Rates Assay}

The superoxide radical $\left(\mathrm{O}_{2}{ }^{--}\right)$scavenging rates of the strains were analyzed following the method of Liu et al. [27] with a small modification. An aliquot $(0.1 \mathrm{~mL})$ of the sample, $2.8 \mathrm{~mL}$ of Tris- $\mathrm{HCl}$ buffer $(0.05 \mathrm{M}, \mathrm{pH} 8.2)$, and $0.1 \mathrm{~mL}$ of pyrogallic acid $(0.05 \mathrm{M})$ comprised the reaction mixture, and it was left to equilibrate for $4 \mathrm{~min}$ at $25^{\circ} \mathrm{C}$ and then were neutralized with $1.0 \mathrm{~mL} \mathrm{HCl}(8 \mathrm{M})$. The reaction mixture absorbance was read at $320 \mathrm{~nm}$. The scavenging rates were calculated according to the following equation:

$$
\text { Scavenging rates }(\%)=\left[1-A_{\text {sample }} / A_{\text {blank }}\right] \times 100 \%
$$

where $A_{\text {sample }}$ represents the absorbance of the test sample and $A_{\text {blank }}$ represents the absorbance of the control reaction without sample.

\subsubsection{Reducing Power Assay}

The method of Oyaizu [28] was used to assess the reducing power. In total, $0.5 \mathrm{~mL}$ of PBS $(0.2 \mathrm{M}, \mathrm{pH} 6.6)$ and $0.5 \mathrm{~mL}$ of potassium ferricyanide $(1 \%$, w/v) were successively mixed with $0.5 \mathrm{~mL}$ of samples. The mixture was rapidly cooled after incubation at $50{ }^{\circ} \mathrm{C}$ for $20 \mathrm{~min}$. Following this, $0.5 \mathrm{~mL}$ of $10 \%$ trichloroacetic acid $(w / v)$ was added to the mixed solution and the new mixture was centrifuged at $5000 \times g$ for $10 \mathrm{~min}$. Next, the supernatant $(1.0 \mathrm{~mL})$ was added to $1.0 \mathrm{~mL}$ of ferric chloride $(0.1 \%, w / v)$ and incubated for $10 \mathrm{~min}$. Finally, the absorbance of the resultant mixture was recorded at $700 \mathrm{~nm}$.

\subsubsection{Measurement of Antioxidant Enzyme Activities}

SOD and GHS-Px activities and the T-AOC of the intracellular cell-free extracts were measured using commercially available assay kits (Nanjing Jiancheng Bioengineering Institute, Nanjing, China). The activities of SOD and GSH-Px were expressed as $\mathrm{nmol} / \mathrm{mg}$ protein.

\subsection{Statistical Analysis}

All experiment trials were repeated three times, with each test being performed three times. All data were expressed as mean values \pm standard errors, and they were evaluated by a general linear model procedure (Statistix 8.1 Analytical Software, St Paul, MN, USA). Statistical differences between different experimental groups were analyzed by one-way analysis of variance (ANOVA) with Tukey's multiple comparisons. 


\section{Results and Discussion}

\subsection{Survival of the Strains under Oxidative Stress}

When LAB are used as functional starters, their resistance to oxidative stress is essential to the production of fermented foods. The colony counts of P. pentosaceus R1 and L. fermentum $\mathrm{R} 6$ were significantly decreased with increasing $\mathrm{H}_{2} \mathrm{O}_{2}$ concentrations $(p<0.05$; Figure $1 \mathrm{~A}$ ). $\mathrm{H}_{2} \mathrm{O}_{2}$ is the most commonly used oxidizing agent and can generate various ROS in bacteria, resulting in oxidative stress and leading to protein, fat, and DNA damage [29]. Generally, LAB are tolerant to oxidative stresses, as they can scavenge free radicals through their redox system and intracellular antioxidant compounds [16]. However, metabolic disturbance and death of cells can occur when the rate of ROS production exceeds the antioxidant capacity of the LAB [30]. Hence, a decrease in colony counts of both strains compared with the control may be due to the $\mathrm{H}_{2} \mathrm{O}_{2}$-induced excessive $\mathrm{ROS}$ production, resulting in the metabolic disturbance and the death of partial cells. In addition, the colony counts of $P$. pentosaceus $\mathrm{R} 1$ in the $3 \mathrm{mM} \mathrm{H}_{2} \mathrm{O}_{2}$-treated group showed a significantly higher value than those of L. fermentum R6 $(p<0.05)$, which revealed that the tolerance of $P$. pentosaceus $\mathrm{R} 1$ to $3 \mathrm{mM} \mathrm{H}_{2} \mathrm{O}_{2}$ was stronger than that of L. fermentum R6. A similar result was proved by our previous report by Chen et al. [4], who investigated the antioxidative activities of both strains and found that P. pentosaceus R1 showed a higher radical scavenging activity and reducing power than L. fermentum R6. As described by Feng and Wang [15], the antioxidant mechanisms of LAB are complex, and different LAB species may rely on different mechanisms of defense against oxidative stress, which may explain why the tolerance of P. pentosaceus $\mathrm{R} 1$ to $\mathrm{H}_{2} \mathrm{O}_{2}$ was stronger than that of L. fermentum R6.
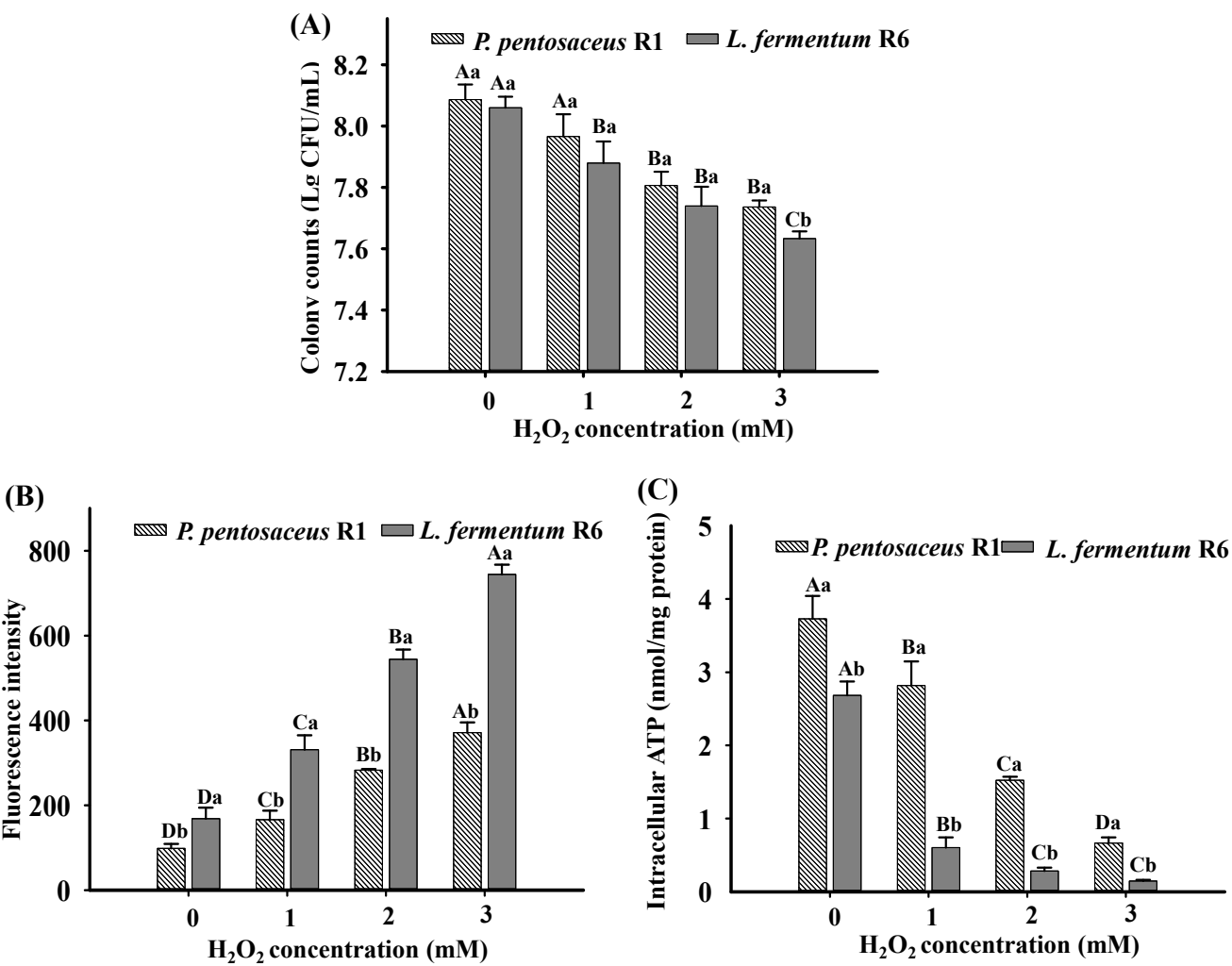

Figure 1. Changes in colony counts (A), intracellular reactive oxygen species (ROS) levels (B), and intracellular ATP concentrations (C) of Pediococcus pentosaceus R1 and Lactobacillus fermentum R6 incubated in MRS broth with different $\mathrm{H}_{2} \mathrm{O}_{2}$ concentrations for $1 \mathrm{~h}$. Different uppercase letters (A-D) denote statistical differences $(p<0.05)$ within the same strain under different $\mathrm{H}_{2} \mathrm{O}_{2}$ concentrations; different lowercase letters $(a$ and $b)$ denote statistical differences $(p<0.05)$ for both strains within the same $\mathrm{H}_{2} \mathrm{O}_{2}$ concentration. 


\subsection{Intracellular ROS Levels}

Excessive ROS production can disturb cellular homeostasis, lead to the oxidative damage of cellular components, and induce changes in bacterial growth kinetics and physiological function [31]. To verify the presence of oxidative stress induced by $\mathrm{H}_{2} \mathrm{O}_{2}$, intracellular ROS levels of P. pentosaceus $\mathrm{R} 1$ and L. fermentum $\mathrm{R} 6$ in all groups were measured. As shown in (Figure 1B), $\mathrm{H}_{2} \mathrm{O}_{2}$ treatment of both strains resulted in significantly increased ROS levels in an $\mathrm{H}_{2} \mathrm{O}_{2}$ dose-dependent manner $(p<0.05)$, which confirmed that the increased $\mathrm{H}_{2} \mathrm{O}_{2}$ concentrations accelerated intracellular ROS accumulation in both strains. A similar result was also emphasized by Liu et al. [32], who found that the intracellular ROS levels in Candida oleophila increased with $\mathrm{H}_{2} \mathrm{O}_{2}$ treatment. Importantly, the increase in ROS levels in both strains treated with $\mathrm{H}_{2} \mathrm{O}_{2}$ compared with the control was reflected in the decreased colony counts of the strains when exposed to oxidative stress, which follows the results illustrated in (Figure 1A). $\mathrm{H}_{2} \mathrm{O}_{2}$ was used as an inducer of oxidative stress, which can react with ferrous iron and produce extremely toxic $\bullet \mathrm{OH}$ by the Fenton reaction and cause severe cellular protein damage and break phosphodiester bonds in DNA molecules. The accumulation of oxidation byproducts can react with lipid moieties within the plasma membrane and further induce cell oxidative damage, triggering an oxidation chain reaction and resulting in a rapid accumulation of ROS [15].

\subsection{Intracellular ATP Concentrations}

As a vital representative of energy metabolism, ATP plays an important role in many biological functions, including growth, survival, and replication, and is involved in stress responses [33]. To evaluate whether oxidative stress influences the energy metabolism of the two strains, intracellular ATP concentrations were evaluated. As shown in Figure 1C, ATP concentrations decreased in both strains with increasing $\mathrm{H}_{2} \mathrm{O}_{2}$ concentration. Compared to the control, the ATP levels in P. pentosaceus R1 and L. fermentum R6 were reduced by about $82 \%$ and $95 \%$ at $3 \mathrm{mM} \mathrm{H}_{2} \mathrm{O}_{2}$, respectively. As is well established, oxidative stress can cause changes in many biological processes of cells, and ATP is essential in many biological processes as an important energy-supply molecule. It is well-documented that the excess in $\mathrm{ROS}$ induced by $\mathrm{H}_{2} \mathrm{O}_{2}$ can severely impair the cell respiratory chain, leading to a decrease in ATP levels [34]. Meanwhile, the ROS, especially extremely toxic $\bullet \mathrm{OH}$, can damage proteins, leading to a lower intracellular energy level [15]. Moreover, Jozefczuk et al. [35] concluded that all three major ATP-production pathways, the metabolism of glycolysis, the pentosephosphate pathway, and the tricarboxylic acid cycle, in Escherichia coli suffered from oxidative damage under oxidative stress, leading to a decrease in ATP levels. In addition, oxidative damage repair is an important way by which bacteria deal with oxidative stress, and this process consumes large amounts of ATP [36]. Therefore, the decreased ATP concentrations in both strains under $\mathrm{H}_{2} \mathrm{O}_{2}$ treatment may be ascribed to the oxidative stress induced by $\mathrm{H}_{2} \mathrm{O}_{2}$ leads to the destruction of the ATP production pathways and/or the consumption of ATP in order to repair oxidative damage.

\subsection{SEM Analysis}

The SEM images show changes in the cell morphology of the two bacteria after exposure to $\mathrm{H}_{2} \mathrm{O}_{2}$ at different concentrations. Compared with the control, the cell morphology of the two strains showed no obvious change when treated with $1 \mathrm{mM} \mathrm{H}_{2} \mathrm{O}_{2}$. However, when the $\mathrm{H}_{2} \mathrm{O}_{2}$ concentration increased, some particles accumulated on the cell surface of P. pentosaceus R1 (Figure 2). According to Gray and Jakob [37], these particles might be inorganic polyphosphates, universally conserved biopolymers with oxidative stress resistance that have multiple functions in increasing bacterial oxidative stress resistance, such as preventing the aggregation of oxidative-damage proteins, reducing free radical concentrations via chelating metal ions, and regulating general stress response pathways in different bacteria. However, the most common ways that bacteria protect themselves against oxidant stress consist in the regulation of enzymatic and non-enzymatic antioxidant defense systems; thus, the protective effect of polyphosphates to P. pentosaceus R1 
deserves future study. For L. fermentum R6, the cell surface changed from smooth to wrinkle with the increase in $\mathrm{H}_{2} \mathrm{O}_{2}$ concentrations from $0 \mathrm{mM}$ to $3 \mathrm{mM}$. A potential explanation for these results may be that oxidative stress can enhance the expression level of matrix metalloproteinases, which can regulate the degradation of the extracellular matrix proteins, resulting in wrinkles [38]. Gallegos-Monterrosa et al. [39] found that the stress induced by hypoxanthine leads to wrinkle formation in Bacillus subtilis 168 and claimed that cell death correlates with wrinkle formation. Based on the information of this entire paragraph, it is tempting to conclude that the P. pentosaceus $\mathrm{R} 1$ presents a more positive defense performance than L. fermentum R6, which may further explain why the tolerance of P. pentosaceus $\mathrm{R} 1$ to $\mathrm{H}_{2} \mathrm{O}_{2}$ was stronger than that of L. fermentum R6 as illustrated in Figure 1A.

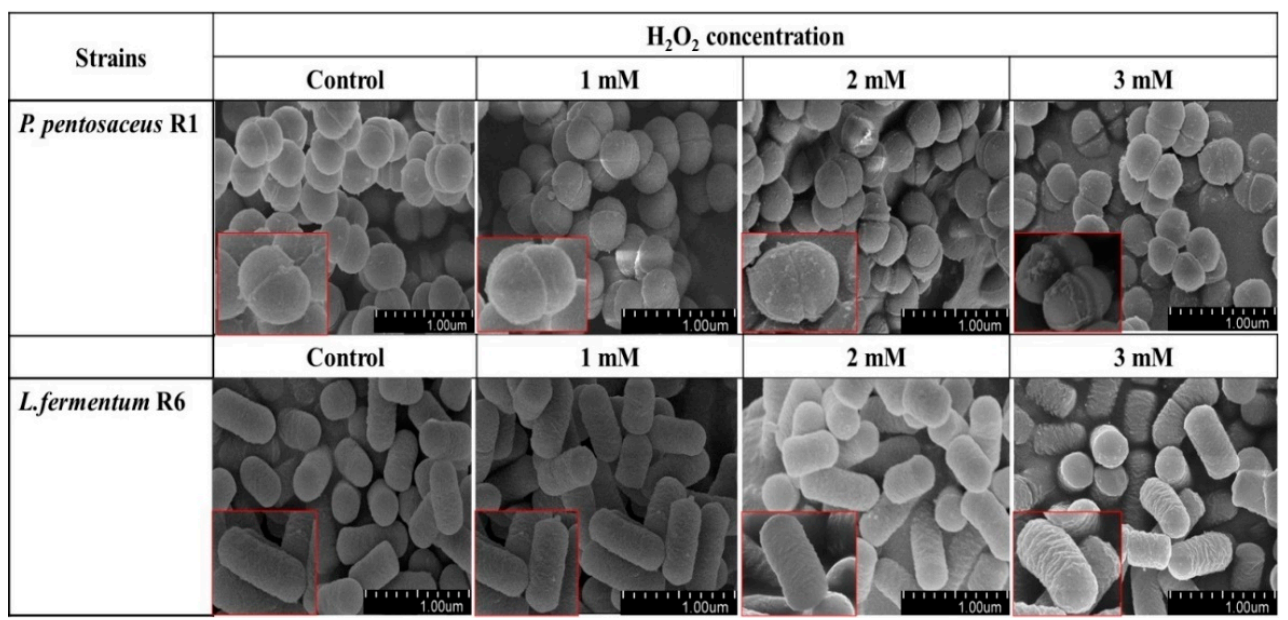

Figure 2. Scanning electron micrographs of Pediococcus pentosaceus R1 and Lactobacillus fermentum R6 incubated in MRS broth with different $\mathrm{H}_{2} \mathrm{O}_{2}$ concentrations for $1 \mathrm{~h}$.

\subsection{TEM Analysis}

TEM was applied to detect the microstructure and more intuitively observe morphological changes of the bacteria after exposure to different concentrations of $\mathrm{H}_{2} \mathrm{O}_{2}$. As shown in (Figure 3), the intracellular organization of both control strains exhibited good integrity and even distribution. However, cell membrane integrity was gradually destroyed and cell cytoplasm was partially lost on $\mathrm{H}_{2} \mathrm{O}_{2}$ treatment. At a higher $\mathrm{H}_{2} \mathrm{O}_{2}$ concentration ( $3 \mathrm{mM}$ ), we observed elongation of the P. pentosaceus R1 and L. fermentum R6 cells, and the L. fermentum R6 cell elongation was gradually aggravated in an $\mathrm{H}_{2} \mathrm{O}_{2}$-concentrationdependent manner. A similar result was illustrated by Guo et al. [40], who found that $\mathrm{NaCl}$ stress results in cell elongation for Escherichia coli and concluded that an appropriate elongation of bacterial cells is beneficial in enhancing resistance to adverse conditions and that bacteria are capable of rapidly reverting to normal cell morphology when the adverse environmental factors are removed. According to Kijima et al. [41] and Mattick et al. [42], the elongation of bacteria cells under stress suppresses cell division and/or DNA synthesis process, which was characterized by avoiding the consumption of ATP to ensure the intracellular ATP was involved in the defense against stress. Therefore, modest changes in morphology are considered an adaptation strategy of bacterial cells to the stressful environment [43].

\subsection{Extracellular Electrolytes}

When the cell membrane is destroyed by the external environment, it will cause a large number of electrolytes to undergo exosmosis, leading to an increase in conductivity; therefore, the evolution of membrane conductivity can be considered to be an indicator of membrane integrity [44]. To observe the impact of $\mathrm{H}_{2} \mathrm{O}_{2}$ stress on the membrane integrity of both strains, the electric conductivity of cell suspensions was measured, as shown in (Figure 4). $\mathrm{H}_{2} \mathrm{O}_{2}$ stress compromised the cell membrane integrity of both strains, as the 
conductivity of both strains gradually increased with the increase in $\mathrm{H}_{2} \mathrm{O}_{2}$ concentration $(p<0.05)$. This observation is consistent with the TEM images presented in (Figure 3$)$, in which it is apparent that the degree of cell membrane damage is positively correlated with $\mathrm{H}_{2} \mathrm{O}_{2}$ concentration. In addition, the conductivity of P. pentosaceus $\mathrm{R} 1$ suspension was lower than that of L. fermentum R6 suspension after treatment with the same $\mathrm{H}_{2} \mathrm{O}_{2}$ concentrations for $60 \mathrm{~min}$, which indicates that the membrane damage degree of P. pentosaceus R1 was lower than that of L. fermentum R6 under the same oxidative stress conditions. This conclusion was consistent with the TEM images observed in Figure 3, which further confirms that the tolerance of P. pentosaceus $\mathrm{R} 1$ to $\mathrm{H}_{2} \mathrm{O}_{2}$ was stronger than that of L. fermentum R6. The bacterial cell envelopes are the first line of defense against stressors for bacteria. When excess ROS is present, the cell envelope stress response is also triggered, and the major components of the bacterial cell wall and cell membrane, i.e., peptidoglycans, surface layer proteins, and phospholipids, are vulnerable, threatening the integrity and viability of the cells $[43,45]$.

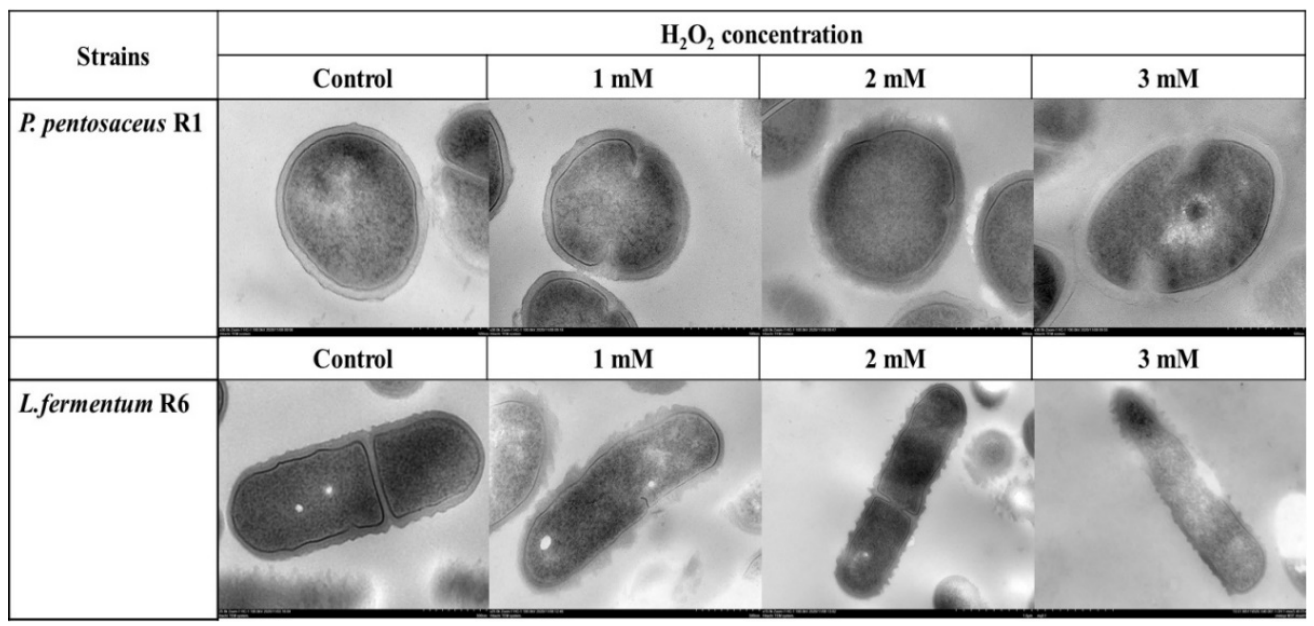

Figure 3. Transmission electron micrographs of Pediococcus pentosaceus R1 and Lactobacillus fermentum R6 incubated in MRS broth with different $\mathrm{H}_{2} \mathrm{O}_{2}$ concentrations for $1 \mathrm{~h}$.
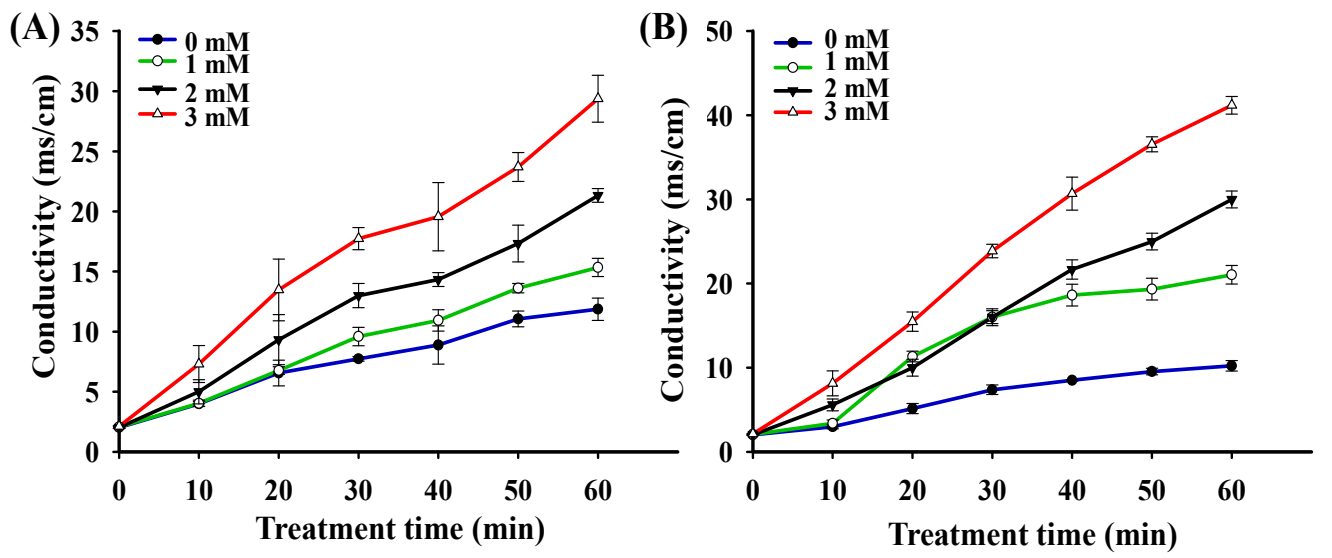

Figure 4. Analysis of electric conductivity of Pediococcus pentosaceus R1 (A) and Lactobacillus fermentum R6 (B) treated with different $\mathrm{H}_{2} \mathrm{O}_{2}$ concentrations for $1 \mathrm{~h}$.

\subsection{Free Radical Scavenging Rates and Reducing Power}

The antioxidant ability of both strains treated with different $\mathrm{H}_{2} \mathrm{O}_{2}$ concentrations was assessed by measuring the scavenging rates of DPPH radical, $\bullet \mathrm{OH}$ radical, and $\mathrm{O}_{2}{ }^{\bullet-}$ radical, and reducing power. As shown in (Figure 5A), the scavenging rates of DPPH radical in P. pentosaceus $\mathrm{R} 1$ increased with increasing $\mathrm{H}_{2} \mathrm{O}_{2}$ concentrations from $0 \mathrm{mM}$ to $2 \mathrm{mM}$ and then decreased at $3 \mathrm{mM} \mathrm{H}_{2} \mathrm{O}_{2}$ for both intact cells and intracellular cell-free 
extractions. For L. fermentum R6, the DPPH radical scavenging rates at $1 \mathrm{mM}$ and $2 \mathrm{mM}$ $\mathrm{H}_{2} \mathrm{O}_{2}$ showed no significant difference $(p>0.05)$ compared with the control but decreased at $3 \mathrm{mM} \mathrm{H}_{2} \mathrm{O}_{2}(p<0.05)$ for both intact cells and intracellular cell-free extractions. As shown in (Figure 5B), the $\bullet \mathrm{OH}$ radical scavenging rates of intact cells in P. pentosaceus R1 treated with all concentrations of $\mathrm{H}_{2} \mathrm{O}_{2}$ were significantly higher than that of the control, and intact cells at $2 \mathrm{mM} \mathrm{H}_{2} \mathrm{O}_{2}$ expressed the maximum scavenging rates $(p<0.05)$; for the intracellular cell-free extraction in P. pentosaceus R1, treatment with $1 \mathrm{mM}$ and $2 \mathrm{mM}$ of $\mathrm{H}_{2} \mathrm{O}_{2}$ resulted in significantly higher $\bullet \mathrm{OH}$ scavenging rates that seen in the control $(p<0.05)$. For L. fermentum R6, intact cells at $1 \mathrm{mM} \mathrm{H}_{2} \mathrm{O}_{2}$ demonstrated the maximum - $\mathrm{OH}$ scavenging rates $(p<0.05)$, which then decreased with increased $\mathrm{H}_{2} \mathrm{O}_{2}$ concentration. The $\bullet \mathrm{OH}$ scavenging rates of the intracellular cell-free extraction of L. fermentum $\mathrm{R} 6$ at $1 \mathrm{mM}$ and $2 \mathrm{mM} \mathrm{H}_{2} \mathrm{O}_{2}$ were not significantly different from the control $(p>0.05)$. This is consistent with the results reported by Amanatidou et al. [46], who claimed that $\bullet \mathrm{OH}$ scavenging levels were similar in Lactobacillus sake cells exposed to anaerobic and high $\mathrm{O}_{2}$ conditions and proposed that the total level of $\bullet \mathrm{OH}$ scavenging of bacteria may be an endogenous property of bacteria and is not regulated by the imposed oxidative stress level. However, the rate at $3 \mathrm{mM} \mathrm{H}_{2} \mathrm{O}_{2}$ was significantly lower than the control $(p<0.05)$ in our results, which may be ascribed to $3 \mathrm{mM} \mathrm{H}_{2} \mathrm{O}_{2}$ inducing intracellular damage, resulting in decreased $\bullet \mathrm{OH}$ scavenging ability of L. fermentum R6. The $\mathrm{O}_{2}{ }^{\bullet-}$ scavenging rates of intact cells of P. pentosaceus $\mathrm{R} 1$ and the intracellular cell-free extraction of L. fermentum R6 increased at $1 \mathrm{mM}$ and $2 \mathrm{mM} \mathrm{H}_{2} \mathrm{O}_{2}$ and then decreased at $3 \mathrm{mM} \mathrm{H}_{2} \mathrm{O}_{2}(p<0.05)$ (Figure $5 \mathrm{C}$ ). The $\mathrm{O}_{2}{ }^{\bullet-}$ scavenging rates of intact cells of L. fermentum R6 decreased at $3 \mathrm{mM} \mathrm{H}_{2} \mathrm{O}_{2}$ compared with the control. Unexpectedly, the reducing power of both strains showed no significant change with $\mathrm{H}_{2} \mathrm{O}_{2}$ treatment $(p<0.05)$, as shown in (Figure 5D), and the reducing powers of the intact cells of both strains were significantly higher than those of the intracellular cell-free extractions $(p<0.05)$.
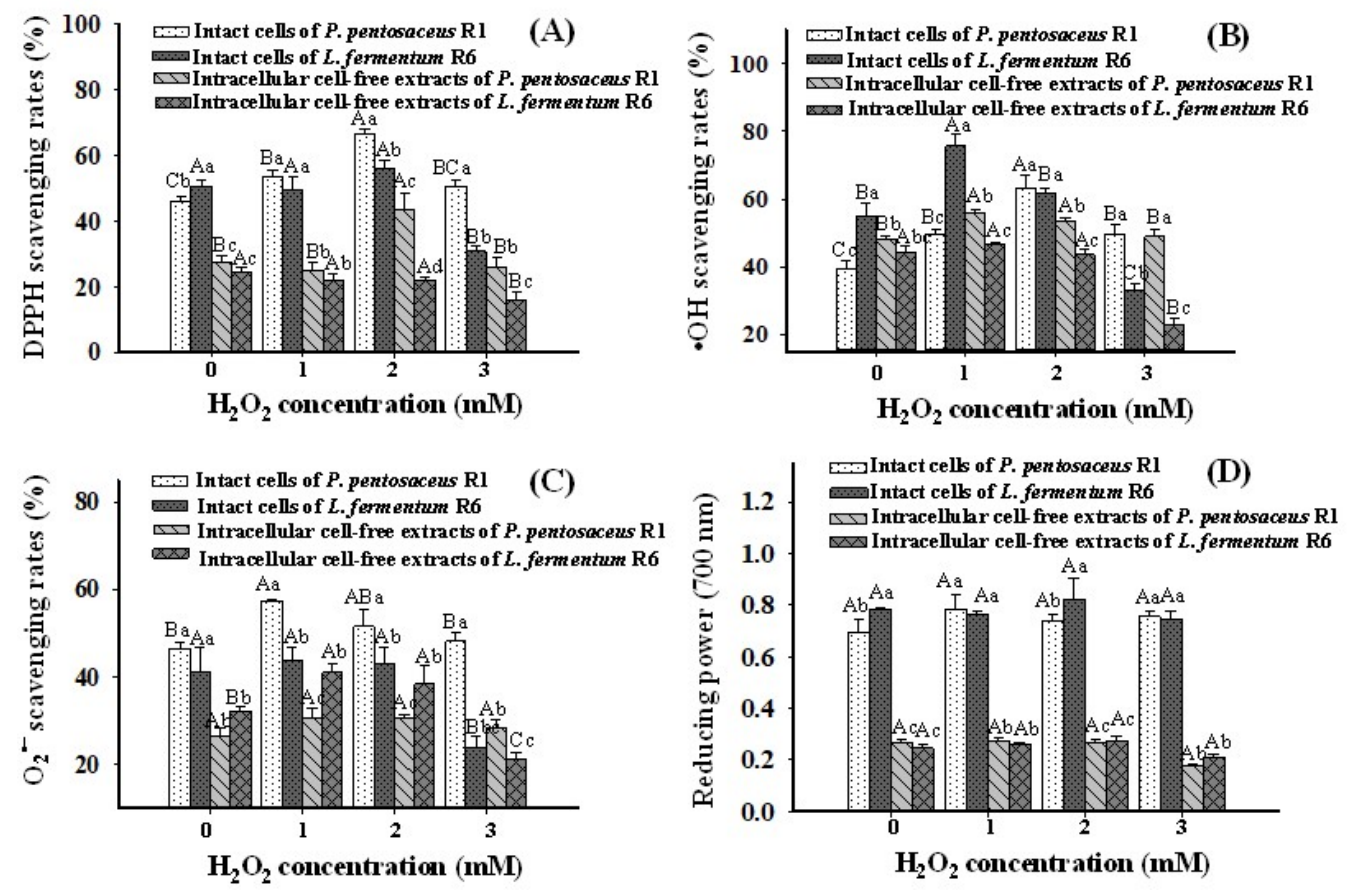

Figure 5. Changes in $2^{\prime}, 2^{\prime}$-diphenyl-1-picrylhydrazyl (DPPH) radical scavenging rates (\%) (A), hydroxyl radical $(\bullet \mathrm{OH})$ scavenging rates $(\%)(\mathbf{B})$, superoxide anion radical $\left(\mathrm{O}_{2}{ }^{\bullet-}\right)$ scavenging rates (\%) (C), and reducing powers (D) of Pediococcus pentosaceus R1 and Lactobacillus fermentum R6 after incubation in MRS broth with different $\mathrm{H}_{2} \mathrm{O}_{2}$ concentrations for $1 \mathrm{~h}$. Different uppercase letters $(\mathrm{A}-\mathrm{C})$ denote statistical differences $(p<0.05)$ of the same components in the same strain (intact cell or intracellular cell-free extract) under different $\mathrm{H}_{2} \mathrm{O}_{2}$ concentrations; different lowercase letters (a-d) denote statistical differences $(p<0.05)$ for both strains within the same $\mathrm{H}_{2} \mathrm{O}_{2}$ concentration. 
In most cases, the ability of the two strains to scavenge various free radicals was improved at $1 \mathrm{mM}$ and $2 \mathrm{mM} \mathrm{H} \mathrm{H}_{2} \mathrm{O}_{2}$ and decreased at $3 \mathrm{mM} \mathrm{H}_{2} \mathrm{O}_{2}$, possibly because the relatively low $\mathrm{H}_{2} \mathrm{O}_{2}$ levels induced the antioxidant defense system, improving antioxidant performance, while $3 \mathrm{mM} \mathrm{H}_{2} \mathrm{O}_{2}$ led to a disruption of the overall metabolic status of the cells and a decrease in free radical scavenging rates [47].

\subsection{Antioxidant Enzyme Activities Analysis}

The SOD and GSH-Px play pivotal roles in the antioxidant defense in cells [48]. Many studies have proven that antioxidant enzymes can act as cell defenders by scavenging ROS [49]. To identify the influence of oxidation on antioxidant capacity, we investigated the SOD and GSH-Px activities and the T-AOC of both strains treated with various $\mathrm{H}_{2} \mathrm{O}_{2}$ concentrations. As shown in Figure 6, $\mathrm{H}_{2} \mathrm{O}_{2}$ treatment notably increased the SOD and GSH-Px activities and increased the T-AOC in P. pentosaceus R1, and the highest SOD and GSH-Px activity levels and T-AOC were observed at $2 \mathrm{mM} \mathrm{H}_{2} \mathrm{O}_{2}(p<0.05)$. The overall activities of SOD and GSH-Px and the T-AOC were drastically reduced in L. fermentum R6 than in P. pentosaceus R1 $(p<0.05)$. These results are in accordance with the phenomenon observed in (Figure 1), confirming that the tolerance of P. pentosaceus R1 to oxidative stress was stronger than that of L. fermentum R6. In addition, $\mathrm{H}_{2} \mathrm{O}_{2}$ concentrations of $1 \mathrm{mM}$ and $2 \mathrm{mM}$ resulted in increased SOD and GSH-Px activities and an increase in the T-AOC in $L$. fermentum R6, while $3 \mathrm{mM} \mathrm{H}_{2} \mathrm{O}_{2}$ induced relatively lower SOD and GSH-Px activities and T-AOC. A similar conclusion was also illustrated by Zhang et al. [45], who investigated the effect of mesotrione-induced oxidative stress on the antioxidant enzyme activities of Chlorella vulgaris. They found that SOD and CAT activities increased upon exposure to $18 \mathrm{mg} / \mathrm{L}$ mesotrione, while $37.5 \mathrm{mg} / \mathrm{L}$ mesotrione resulted in decreased antioxidant enzyme activities and speculated that a high dose of the mesotrione directly inhibited the antioxidant enzyme activities. Meanwhile, our results demonstrated that the ability of the two strains to scavenge various free radicals was effectively improved by enhancing the activities of antioxidant enzymes under oxidative stress. For L. fermentum R6, $3 \mathrm{mM} \mathrm{H}_{2} \mathrm{O}_{2}$ may have caused severe oxidative damage that eventually resulted in significant metabolic perturbations and decreased antioxidant enzyme activity [46]. 


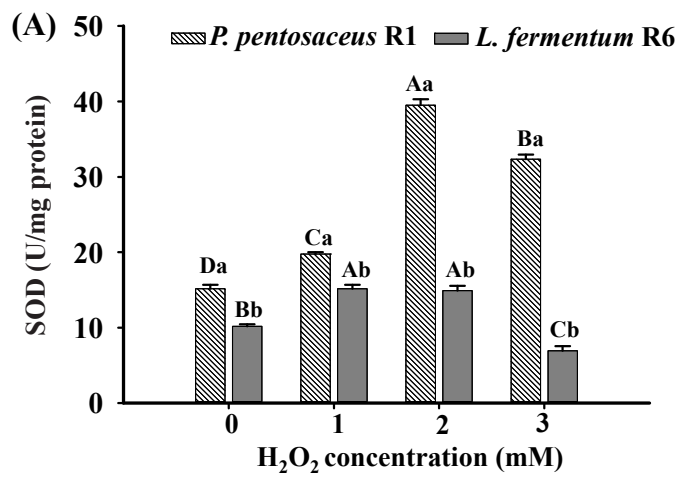

(B)

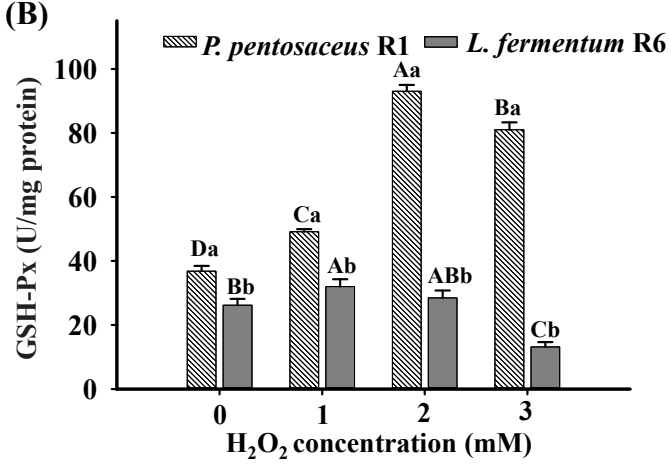

(C)

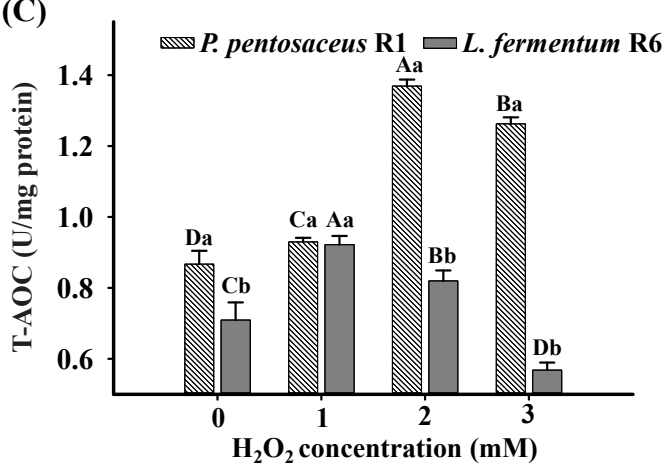

Figure 6. Superoxide dismutase (SOD) activity (A), glutathione peroxide (GSH-Px) activity (B), and total antioxidant capacity (T-AOC) (U/mg protein) (C) of Pediococcus pentosaceus $\mathrm{R} 1$ and Lactobacillus fermentum $\mathrm{R} 6$ after incubation in MRS broth with different $\mathrm{H}_{2} \mathrm{O}_{2}$ concentrations for $1 \mathrm{~h}$. Different uppercase letters $(\mathrm{A}-\mathrm{D})$ denote statistical differences $(p<0.05)$ within the same strain under different $\mathrm{H}_{2} \mathrm{O}_{2}$ concentrations; different lowercase letters $(a$ and $b)$ denote statistical differences $(p<0.05)$ for both strains within the same $\mathrm{H}_{2} \mathrm{O}_{2}$ concentration.

\section{Conclusions}

This study indicated that $\mathrm{H}_{2} \mathrm{O}_{2}$ induced oxidative stress in a dose-dependent manner which seriously affects cell homeostasis, leading to LAB cells' partial death and reduces the intracellular ATP levels. Meanwhile, oxidative stress changed the morphology and reduced the membrane integrity of $P$. pentosaceus R1 and L. fermentum R6. The P. pentosaceus $\mathrm{R} 1$ displayed a stronger defense property than L. fermentum R6, which corresponded to the higher tolerance to $\mathrm{H}_{2} \mathrm{O}_{2}$ and the better antioxidant enzyme activities of P. pentosaceus $\mathrm{R} 1$ than that of L. fermentum R6. In addition, relatively appropriate oxidative stress levels ( 1 and $2 \mathrm{Mm} \mathrm{H}_{2} \mathrm{O}_{2}$ ) triggered antioxidant enzymatic defense system and improved the antioxidant activities of P. pentosaceus R1 and L. fermentum R6. Notably, P. pentosaceus R1 has better antioxidant activity than L. fermentum R6 under some oxidative stress conditions. Overall, P. pentosaceus R1 had better potential than L. fermentum R6 for application as an antioxidant starter in fermented food systems and as probiotic in the functional foods or host's gastrointestinal tract when the cells are exposed to aerobic food or host systems.

Author Contributions: B.K. and Q.C. designed the study and helped revise the manuscript. H.Z. carried out all the experiments and wrote this article. J.X. and H.W. helped analyze the results. All authors have read and agreed to the published version of the manuscript.

Funding: This research were funded by the National Natural Science Foundation of China (Grant NO. 31771990 and 31972139) and the Major Science and Technology Projects of Heilongjiang province (Grant NO. 2020ZX07B02).

Institutional Review Board Statement: Not applicable.

Informed Consent Statement: Not applicable. 
Data Availability Statement: The date presented in this study are available in the article.

Conflicts of Interest: The authors declare no conflict of interest.

\section{References}

1. Bekhit, M.; Arabtehrany, E.; Kahn, C.J.F.; Cleymand, F.; Fleutot, S.; Desobry, S.; Sanchezgonzalez, L. Bioactive films containing alginate-pectin composite microbeads with Lactococcus lactis subsp. lactis: Physicochemical characterization and antilisterial activity. Int. J. Mol. Sci. 2018, 19, 574. [CrossRef]

2. Evivie, S.E.; Huo, G.; Igene, J.O.; Bian, X. Some current applications, limitations and future perspectives of lactic acid bacteria as probiotics. Food Nutr. Res. 2017, 61, 1318034. [CrossRef]

3. Chávarri, M.; Marañón, I.; Ares, R.; Ibáñez, F.C.; Marzo, F.; Villarán, M.C. Microencapsulation of a probiotic and prebiotic in alginate-chitosan capsules improves survival in simulated gastro-intestinal conditions. Int. J. Food Microbiol. 2010, 142, 185-189. [CrossRef]

4. Chen, Q.; Kong, B.; Sun, Q.; Dong, F.; Liu, Q. Antioxidant potential of a unique LAB culture isolated from Harbin dry sausage: In vitro and in a sausage model. Meat Sci. 2015, 110, 180-188. [CrossRef]

5. Peng, K.; Koubaab, M.; Balsa, O.; Vorobieva, E. Recent insights in the impact of emerging technologies on lactic acid bacteria: A review. Food Res. Int. 2020, 137, 109544. [CrossRef]

6. Chen, Q.; Kong, B.; Han, Q.; Xia, X.; Xu, L. The role of bacterial fermentation in lipolysis and lipid oxidation in Harbin dry sausages and its flavour development. LWT 2017, 77, 389-396. [CrossRef]

7. Neffeskocinska, K.; Jaworska, D.; Kolozynkrajewska, D.; Dolatowski, Z.J.; Jachaczjowko, L. The effect of lab as probiotic starter culture and green tea extract addition on dry fermented pork loins quality. Biomed. Res. Int. 2015, 2015, 452757. [CrossRef]

8. Spyropoulos, B.G.; Misiakos, E.P.; Fotiadis, C.; Stoidis, C.N. Antioxidant properties of probiotics and their protective effects in the pathogenesis of radiation-induced enteritis and colitis. Digest. Dis. Sci. 2011, 56, 285-294. [CrossRef]

9. Amaretti, A.; Nunzio, M.; Pompei, A.; Raimondi, S.; Rossi, M.; Bordoni, A. Antioxidant properties of potentially probiotic bacteria: In vitro and in vivo activities. Appl. Microbiol. Biotechnol. 2013, 97, 809-817. [CrossRef] [PubMed]

10. Ferrando, V.; Quiberoni, A.; Reinhemer, J.; Suarez, V. Resistance of functional lactobacillus plantarum strains against food stress conditions. Food Microbiol. 2015, 48, 63-71. [CrossRef]

11. Mills, S.; Stanton, C.; Fitzgerald, G.F.; Ross, R.P. Enhancing the stress responses of probiotics for a lifestyle from gut to product and back again. Microb. Cell Fact. 2011, 10, S19. [CrossRef]

12. Ianni, F.; Altomare, A.A.; Cenci-Goga, B.T.; Blasi, F.; Cossignani, L. Chromatographic characterization and in vitro bioactivity evaluation of Lactobacillus helveticus hydrolysates upon fermentation of different substrates. Appl. Sci. 2021, 11, 811. [CrossRef]

13. Grispoldi, L.; Giglietti, R.; Traina, G.; Cenci-Goga, B. How to assess in vitro probiotic viability and the correct use of neutralizing agents. Front. Microbiol. 2020, 11, 204. [CrossRef]

14. Akhova, A.V.; Sekatskaya, P.A.; Tkachenko, A.G. Formation of associated oxidative stress in cells of Escherichia coli exposed to different environmental stressors. Appl. Biochem. Microbiol. 2019, 55, 582-587. [CrossRef]

15. Feng, T.; Wang, J. Oxidative stress tolerance and antioxidant capacity of lactic acid bacteria as probiotic: A systematic review. Gut Microbes 2020, 12, 1801944. [CrossRef]

16. Papadimitriou, K.; Alegria, A.; Bron, P.A.; De Angelis, M.; Gobbetti, M.; Kleerebezem, M.; Lemos, J.A.; Linares, D.M.; Ross, P.; Stanton, C.; et al. Stress physiology of lactic acid bacteria. Microbiol. Mol. Biol. Rev. 2016, 80, 837-890. [CrossRef]

17. Zotta, T.; Parente, E.; Ricciardi, A. Aerobic metabolism in the genus Lactobacillus: Impact on stress response and potential applications in the food industry. J. Appl. Microbiol. 2017, 122, 857-869. [CrossRef] [PubMed]

18. Zotta, T.; Ricciardi, A.; Ciocia, F.; Rossano, R.; Parente, E. Diversity of stress responses in dairy thermophilic streptococci. Int. J. Food Microbiol. 2008, 124, 34-42. [CrossRef]

19. Leite, M.C.T.; Troxell, B.; Bruno-Bárcena, J.M.; Hassan, H.M. Biology of Reactive Oxygen Species, Oxidative Stress, and Antioxidants in Lactic Acid Bacteria; Caister Academic Press: Wymondham, UK, 2015; pp. 205-218.

20. Zhao, Y.C.; Li, J.L.; Chen, Y.R.; Hang, H.X. Response to oxidative stress of Coriolus versicolor induced by exogenous hydrogen peroxide and paraquat. Ann. Microbiol. 2009, 59, 221-227. [CrossRef]

21. Bai, Z.H.; Harvey, L.M.; McNeil, B. Physiological responses of chemostat cultures of Aspergillus niger (B1-D) to simulated and actual oxidative stress. Biotechnol. Bioeng. 2003, 82, 691-701. [CrossRef]

22. Han, Q.; Kong, B.; Chen, Q.; Sun, F.; Zhang, H. In vitro comparison of probiotic properties of lactic acid bacteria isolated from harbin dry sausages and selected probiotics. J. Funct. Foods. 2017, 32, 391-400. [CrossRef]

23. Sanhueza, E.; Paredes-Osses, E.; Gonzalez, C.L.; Garcia, A. Effect of pH in the survival of Lactobacillus salivarius strain UCO_979C wild type and the $\mathrm{pH}$ acid acclimated variant. Electron. J. Biotechnol. 2015, 18, 343-346. [CrossRef]

24. Ngamdee, W.; Tandhavanant, S.; Wikraiphat, C.; Reamtong, O.; Wuthiekanun, V.; Salje, J.; Low, D.A.; Peacock, S.J.; Chantratita, N. Competition between Burkholderia pseudomallei and B. thailandensis. BMC Microbiol. 2015, 15, 56. [CrossRef] [PubMed]

25. Tao, Y.; Qian, L.H.; Xie, J. Effect of chitosan on membrane permeability and cell morphology of Pseudomonas aeruginosa and Staphyloccocus aureus. Carbohyd. Polym. 2011, 86, 969-974. [CrossRef]

26. Wang, A.N.; Yi, X.W.; Yu, H.F.; Dong, B.; Qiao, S.Y. Free radical scavenging activity of Lactobacillus fermentum in vitro and its antioxidative effect on growing-finishing pigs. J. Appl. Microbiol. 2009, 107, 1140-1148. [CrossRef] 
27. Liu, W.; Wang, H.; Pang, X.; Yao, W.; Gao, X. Characterization and antioxidant activity of two low-molecular-weight polysaccharides purified from the fruiting bodies of Ganoderma lucidum. Int. J. Biol. Macromol. 2010, 46, 451-457. [CrossRef]

28. Oyaizu, M. Studies on products of browning reaction-antioxidative activities of products of browning reaction prepared from glucosamine. J. Acad. Nutr. Diet. 1986, 44, 307-315. [CrossRef]

29. Arcanjo, N.O.; Andrade, M.J.; Padilla, P.; Rodriguez, A.; Madruga, M.S.; Estevez, M. Resveratrol protects Lactobacillus reuteri against $\mathrm{H}_{2} \mathrm{O}_{2}$-induced oxidative stress and stimulates antioxidant defenses through upregulation of the dhaT gene. Free Radic. Biol. Med. 2019, 135, 38-45. [CrossRef]

30. Qian, J.; Wang, C.; Zhuang, H.; Zhang, J.; Yan, W. Oxidative stress responses of pathogen bacteria in poultry to plasma-activated lactic acid solutions. Food Control 2020, 118, 107355. [CrossRef]

31. Serrazanetti, D.I.; Guerzoni, M.E.; Corsetti, A.; Vogel, R. Metabolic impact and potential exploitation of the stress reactions in lactobacilli. Food Microbiol. 2009, 26, 700-711. [CrossRef]

32. Liu, J.; Wisniewski, M.; Droby, S.; Norelli, J.; Hershkovitz, V.; Tian, S.P.; Farrell, R. Increase in antioxidant gene transcripts, stress tolerance and biocontrol efficacy of Candida oleophila following sublethal oxidative stress exposure. FEMS Microbiol. Ecol. 2012, 80, 578-590. [CrossRef]

33. Nie, F.; Zhang, X.; Qi, Q.; Yang, L.; Yang, Y.; Liu, W.; Lu, N.; Wu, Z.; You, Q.; Guo, Q. Reactive oxygen species accumulation contributes to gambogic acid-induced apoptosis in human hepatoma SMMC-7721 cells. Toxicology 2009, 260, 60-67. [CrossRef]

34. Bignucolo, A.; Appanna, V.P.; Thomas, S.C.; Auger, C.; Han, S.W.; Omri, A.; Appanna, V.D. Hydrogen peroxide stress provokes a metabolic reprogramming in Pseudomonas fluorescens: Enhanced production of pyruvate. J. Biotechnol. 2013, 167, 309-315. [CrossRef]

35. Jozefczuk, S.; Klie, S.; Catchpole, G.; Szymanski, J.; Cuadros-Inostroza, A.; Steinhauser, D.; Selbig, J.; Willmitzer, L. Metabolomic and transcriptomic stress response of Escherichia coli. Mol. Syst. Biol. 2010, 6, 364. [CrossRef]

36. Balamurugan, S. Growth temperature associated protein expression and membrane fatty acid composition profiles of Salmonella enterica serovar Typhimurium. J. Basic. Microb. 2010, 50, 507-518. [CrossRef]

37. Gray, M.J.; Jakob, U. Oxidative stress protection by polyphosphate-New roles for an old player. Curr. Opin. Microbiol. 2015, 24, 1-6. [CrossRef] [PubMed]

38. Pavida, P.; Jitlada, M.; Ornicha, P.; Mayumi, K.; Mamitaro, O. Role of Matrix Metalloproteinases in Photoaging and Photocarcinogenesis. Int. J. Mol. Sci. 2016, 17, 868. [CrossRef]

39. Gallegos-Monterrosa, R.; Kankel, S.; Götze, S.; Barnett, R.; Stallforth, P.; Kovács, Á.T. Lysinibacillus fusiformis M5 induces increased complexity in Bacillus subtilis 168 colony biofilms via hypoxanthine. J. Bacteriol. 2017, 199, e00204-17. [CrossRef]

40. Guo, Y.; Dong, Y.; Hong, X.; Pang, X.; Chen, D.; Chen, X. Directed evolution of dunaliella salina Ds-26-16 and salt-tolerant response in Escherichia coli. Int. J. Mol. Sci. 2016, 17, 1813. [CrossRef] [PubMed]

41. Kijima, N.; Goyal, D.; Takada, A.; Wachi, M.; Nagai, K. Induction of only limited elongation instead of filamentation by inhibition of cell division in Corynebacterium glutamicum. Appl. Microbiol. Biotechnol. 1998, 50, 227-232. [CrossRef]

42. Mattick, K.L.; Jørgensen, F.; Legan, J.D.; Cole, M.B.; Porter, J.; Lappinscott, H.M.; Humphrey, T.J. Survival and filamentation of Salmonella enterica Serovar Enteritidis PT4 and Salmonella enterica Serovar Typhimurium DT104 at low water activity. Appl. Environ. Microbiol. 2000, 66, 1274-1279. [CrossRef]

43. Ultee, E.; Ramijan, K.; Dame, R.T.; Briegel, A.; Claessen, D. Stress-induced adaptive morphogenesis in bacteria. Adv. Microb. Physiol. 2019, 74, 97-141. [CrossRef]

44. Lu, J.; Wang, Z.; Ren, M.; Huang, G.; Fang, B.; Bu, X.; Liu, Y.; Guan, S. Antibacterial effect of gallic acid against Aeromonas hydrophila and Aeromonas sobria through damaging membrane integrity. Curr. Pharm. Biotechnol. 2016, 17, 1153-1158. [CrossRef]

45. Zhang, F.; Yao, X.; Sun, S.; Wang, L.; Wang, J. Effects of mesotrione on oxidative stress, subcellular structure, and membrane integrity in Chlorella vulgaris. Chemosphere 2019, 247, 125668. [CrossRef] [PubMed]

46. Amanatidou, A.; Smid, E.J.; Bennik, M.H.J.; Gorris, L.G.M. Antioxidative properties of Lactobacillus sake upon exposure to elevated oxygen concentrations. FEMS Microbiol. Lett. 2001, 203, 87-94. [CrossRef]

47. Collins, E.B.; Aramaki, K. Production of hydrogen peroxide by Lactobacillus acidophilus. J. Dairy Sci. 1980, 63, 353-357. [CrossRef]

48. Toscano, S.; Farieri, E.; Ferrante, A.; Romano, D. Physiological and biochemical responses in two Ornamental Shrubs to drought stress. Front. Plant Sci. 2016, 7, 645. [CrossRef] [PubMed]

49. Urushihara, Y.; Kawasumi, K.; Endo, S.; Tanaka, K.; Hirakawa, Y.; Hayashi, G.; Sekine, T.; Kino, Y.; Kuwahara, Y.; Suzuki, M.; et al. Analysis of plasma protein concentrations and enzyme activities in cattle within the ex-evacuation zone of the fukushima daiichi nuclear plant accident. PLoS ONE 2016, 11, e0155069. [CrossRef] 